\title{
Tax Planning of a Company Operating Foreign Activity in Malaysia
}

\author{
Zaimah Zainol Ariffin
}

\begin{abstract}
Corporate tax planning studies have been addressed for a number of years within the developed market context, whereas corporate tax planning research for companies in developing countries is largely non-existent. Studies also associate corporate tax planning with tax avoidance. Tax collection generates large amounts of revenue and is a vital source of income for government to promote overall economic stability and growth. Since Malaysia implemented self-assessment system for companies in 2001, it is important to ensure compliance by taxpayers. Companies engaging with foreign activities are able to utilize in international tax planning. This study is aimed to examine the influence of companies engaging in foreign activity on corporate tax planning. This study tests the relationship by using a cross-sectional-time series valuation using panel data analyses which is Tobit estimations. The findings indicate the link between companies engaging in foreign activity and corporate tax planning in an emerging market.
\end{abstract}

Index Terms-Corporate tax planning, corporate tax avoidance, foreign activity.

\section{INTRODUCTION}

In Malaysia, income tax revenue is a major contributor to Malaysian government revenues. Income tax revenues represent approximately 50 percent of the total revenue of the Federal Government of Malaysia [1]. Deputy Minister of Finance Datuk Chan Kong Choy reported that although tax collection reached a record high (RM45 billion) in 2002, the number of defaulters are also believed to have increased. By July 2002, over 13,000 individuals owing some RM1 billion in taxes were barred from leaving the country. This compares to fewer than 4,000 in 2001. Therefore, it is believed that tax avoidance or aggressive tax planning activity is increasing over time.

Tax evasion is always against the law. It is the activity of not paying taxes either by under-declaring income or overdeclaring deductions or exemptions. On the other hand, tax avoidance is legal, but taxpayers are hidden behind tax planning to lower the tax burden. The growth in corporate tax avoidance activities are a reflection of the more accepting attitudes of tax advisors and corporate executives towards engaging in aggressive tax planning. Thus, this is an interesting phenomenon that needs to be studied.

Tax planning not implies any conscious wrongdoing, but merely the planning process to find some structural defect or loophole in the tax legislation which resulted in paying

Manuscript received April 16, 2013; revised June 26, 2013.

Zaimah Zainol Ariffin is with Universiti Utara Malaysia (e-mail: zaimah@uum.edu.my). less tax than otherwise required. An example of such a loophole enables the common practice of tax planning through transfer pricing, where profit or income is shifted between countries. With different tax rates or systems to avoid the total amount of tax payable, tax planning also includes income shifting, investing in loss companies, income splitting and gift schemes. Most research on corporate tax planning has been conducted in the US, the UK and Australia. This study investigates corporate tax planning in Malaysia, thus adding to the corporate tax planning literature by examining an emerging market.

The Malaysian economy is dependent on foreign activity. As the operations of Malaysian companies become increasingly global in scope, an important issue is how their foreign activities impact on their tax planning. Companies engaging in foreign activity are fundamentally different from domestic only companies as they operate in different cultural, political, economic environments and different tax legislations and jurisdictions.

The objective of this study is to examine whether or not the companies engaging in foreign activity in emerging country (Malaysia) would also engage in tax planning. The findings of this study are expected to provide new evidence on the effect of companies' foreign activities on corporate tax planning.

\section{PRIOR RESEARCH}

\section{A. Theoretical Background}

Based on the underlying premise that decisions about corporate tax planning are made by companies' managers, [2] emphasized that a principal-agent model is more appropriate when discussing corporate behavior. As such, this study presents a principal-agent model in incorporating the possibility that the manager (agent) may have two motivations, namely synergy and agency when they get involved in their tax avoiding or tax planning activities. In addition to synergy and agency, there is also possibility of hubris occurring that motivate tax avoidance.

This study proposes that in any (aggressive) tax planning activity, elements of synergy, agency and hubris simultaneously exist and interact to determine the output of the activity. These theories aim to identify the economic motives that influence managers to make certain choices. Thus, this study attempts to adapt and provide additional evidence on the principal-agent model of tax planning behavior.

\section{B. Tax Planning}

Tax planning will reduce the present value of tax payments and lower the effective tax rates. Previous 
research considers effective tax rates (ETR) as a measure of effective tax planning (for example, see [3] and [4]). Academic researchers and policymakers have also been using ETR as an important measurement of the corporate tax burden for several decades (for example, see [5]-[8]). [5] interpreted ETR as a measure of the effectiveness of tax planning. Similar to [3]-[5], this study also utilizes the concept of effective tax rates (ETR) since it is considered the most appropriate tool to measure the distribution of a company's tax burden.

The analysis of this study utilizes the concept of ETR since it is the most appropriate tool to measure the distribution of a company's tax burden. This measurement was in line with [5]'s proxy for tax avoidance (aggressive tax planning) that is also consistent with the studies of [3] and [4]. ETR is measured as the ratio of current income tax expense to income before income tax.

\section{Foreign Activity}

There are several aspects for companies engaging in foreign activity to lower their effective tax rates. Companies engaging in foreign operations have opportunities to avoid income taxation by locating operations in low-tax foreign jurisdiction; shifting income from high-tax jurisdictions to low-tax jurisdictions; exploiting differences between the tax rules of different countries and taking advantage of tax benefits agreements with host countries.

These activities may enable companies to lower their effective tax rates. According to [9], corporations engaging in foreign operations may have significantly greater opportunities to escape tax with respect to cross-border investments than domestic only corporations.

There are a number of foreign jurisdictions that offer corporate income tax rates which are lower than the Malaysian corporate tax rate of $28 \%$ (2006), such as Singapore (20\%) and Hong Kong (17.5\%). The benefit of operating in low tax foreign jurisdiction is that it will lower the corporate tax expense and in turn, the corporate effective tax rate. In contrast, corporate income tax rates exceed the Malaysian corporate tax rate is in Indonesia (30\%), Thailand (30\%) and Philippines $(35 \%)$ in the ASEAN region. It is common for Malaysian corporations to have operations in both high and low foreign tax jurisdiction, but one would expect that the corporations would engage more in low tax foreign jurisdictions than high tax foreign jurisdictions. Despite the advantage of cross-border activity, the Malaysian tax code also provides tax benefits towards foreign operation activities.

Studies, mainly in developed countries, have documented that companies engaging in foreign activity report significantly lower taxable income compared to domestic only companies. One would expect that corporate taxes are controllable through planning, and [10] provides evidence that U.S corporations with foreign operations employ a wide variety of international tax planning strategies. According to [5,p.813), companies with foreign operations "have opportunities to avoid income taxes by locating operations in low-tax countries, by shifting income from high-tax locations to low-tax locations, by exploiting differences in the tax rules of different countries, by engaging in complex property transactions and by taking advantage of tax subsidy agreement with host countries."

[9] suggests that companies with foreign operations could avoid or reduce their tax burden since they have greater opportunities to escape tax with respect to cross-border investments than with respect to strictly domestic investments. However, in contrast with [9]'s assertions, [11] contend that empirical findings are insufficient and inconclusive and fail to provide conclusive evidence that companies engaging in foreign activity pay less income tax than domestic only companies.

[12] investigate the variation of ETR in Australian large business and international companies. The results indicate that the foreign income variable has a negative sign for all four years and are significantly negatively related to ETR for the latter two years. They argue that this provides evidence that companies may be using their foreign operations to lower their domestic ETR.

[5] revealed that multinational US companies with more extensive foreign operations reported lower effective tax rates than domestic only companies. She also indicated that, this was due to several taxes avoidance strategies such as creation of book-tax differences and income shifting from high tax jurisdictions to low tax jurisdictions.

Hence, several studies provide evidence that companies engaging in foreign activity might be tempted to shift taxable income to low tax jurisdictions. As Malaysia is already a relatively low-tax jurisdiction, the aggressiveness of tax avoidance or tax planning activity between companies engaging in foreign activity and domestic only companies may be limited. However, it is expected that companies with extensive foreign activity will exploit tax minimization strategies more aggressively than their counterparts with less extensive foreign activity companies.

\section{Methodology}

At the initial stage, this study selected the full population of companies listed on Bursa Malaysia from 2001 to 2005. The year 2001 was selected as it was the first year of the self-assessment system implementation in Malaysia. The data were in the form of panel data.

The data were collected from the annual report in the Thomson Analytic Database for 2001 - 2005, resulting in 5,000 observations. Table I summarizes the sample selection procedures. Banking and insurance companies were excluded because they are subject to different legislation from the other companies, highly regulated and relatively 'safe' in Malaysia (740 firm-years). These criteria may affect their ETR practices differently than the other companies. In addition, companies with zero income or losess $(1,970)$ were also dropped from the analysis, following previous studies (for example, see [5], [13] and [14]) omitted companies with losses or zero income. These companies will create negative values for ETR which is not susceptible of economic interpretation in this context. In addition, most of the loss-making companies in the data set were loss-making for the entire period of the study. Thus, to be consistent with prior studies, this study also omitted company-year observations with losses or zero income which resulted in 1,970 firm-years. Firm-years with incomplete ETR data were also excluded (645 firm-years). 
The final sample comprises 1,645 firm-year observations as shown in Table I.

TABLE I: SAMPLE SELECTION PROCEDURE

\begin{tabular}{lr}
\hline \hline Number of firm-years 2001 - 2005 & 5,000 \\
Less: & $(740)$ \\
Banking and insurance companies & $(1,970)$ \\
Companies-years with loss or zero income & $(645)$ \\
Companies-years with missing ETR data & 1,645 \\
\hline Number of firm-years available for ETR analysis & \\
\end{tabular}

The data relating to the dependent variable values of ETR were censored by means of truncation at both sides of ETRs to remove the most extreme negative and positive observations and restrict the effect of potential bias [14]. The observations with either an ETR greater than double the statutory tax rate (56 per cent), or a negative/zero ETR were deleted. Therefore only those companies with an ETR in the range between 0 per cent and 56 per cent were considered. The definition and measurement of the variables are explained in Table II.

TABLE II: THE DEFINITION AND MEASUREMENT OF VARIABLES

\begin{tabular}{lll}
\hline \hline Variables & Definitions & Measurement \\
\hline ETR & Effective Tax & Natural log of ETR \\
& Rates & \\
DFA & Foreign Activity & 1, if firm reporting foreign \\
& Dummy & assets or foreign operations, \\
& Variable & and 0 otherwise. \\
FA & Foreign Activity & $\begin{array}{l}\text { Ratio of foreign sales to total } \\
\text { sales }\end{array}$ \\
\hline \hline
\end{tabular}

The natural logarithmic transformation is used in ETR and FA variables to reduce the skewness of the distribution and to minimize the standard error of the regression coefficient. Two different proxies for foreign activity are used in the empirical test, which are DFA and FA. The foreign activity dummy variable $(D F A)$ is used to indicate whether companies engage in foreign activity or not. Value 1 was given if a firm reports foreign income or foreign assets and zero otherwise. This is to determine whether companies which engage in foreign activity have lower or higher ETR than companies which do not engage in foreign activity. In contrast to the foreign activity dummy variable, $D F A, F A$ is a continuous variable and is the ratio of foreign sales to total sales, which determines whether companies with extensive foreign operations have lower or higher ETR than companies with less extensive foreign operations.

\section{FINDINGS AND DISCUSSION}

Table III shows the results of the tobit censored regression model of the dependent variable, ETR as to estimated coefficients for the foreign activity, DFA and FA.

The result shows that foreign activity (FA) possess a significant influence on ETR with the expected direction, whereas foreign activity dummy variable (DFA) has a significant influence on ETR but it is not in the expected direction.

\section{A. Foreign Activity Dummy Variable (DFA)}

A significant positive sign for the foreign activity dummy variable, which is not as expected sign, suggests that companies that engage in foreign activity have higher ETR than companies who do not engage in foreign activity. The finding contradicts [9] who claimed that companies engage in foreign operation may have significantly greater opportunities to escape tax with respect to cross-border investments than with respect to strictly domestic investments. The finding might offer support for the contention that the costs of tax planning should be lower for companies that operate in low-tax jurisdiction, as Malaysia can be considered a low-tax country compared to European countries or those in the Asean region. For example, the company tax rate in Singapore 20\%, Malaysia 28\%, Thailand 30\% and Philippine 35\%. Malaysia has the second lowest tax rate in Asean countries after Singapore. In addition to that, companies engaging in foreign operation might be subject to higher foreign statutory tax rates compared to the Malaysian tax rate. Thus, due to higher foreign statutory tax rates, this factor may produce a positive relationship between companies engaging in foreign operation and ETR.

TABLE III: TAX PLANNING ACTIVITY

\begin{tabular}{|l|c|c|}
\hline $\begin{array}{c}\text { Explanatory } \\
\text { Variables }\end{array}$ & Expected Sign & $\begin{array}{c}\text { Coefficient } \\
\text { (Std Error) }\end{array}$ \\
\hline Constant & & $\begin{array}{c}-3.2457 * \\
(.4268)\end{array}$ \\
\hline DFA & - & $\begin{array}{c}.2729 * * \\
(.1205)\end{array}$ \\
\hline FA & $-.0052^{*}$ \\
& $(.0025)$ \\
\hline LR chi2 & 75.55 \\
\hline Prob > chi2 & 0.0000 \\
\hline Pseudo R2 & 0.0246 \\
\hline Number of observations & 887 \\
\hline Left-Censored Observations & 158 \\
\hline Right-Censored Observations & 18 \\
\hline Uncensored Observations & 711 \\
\hline $\begin{array}{l}\text { Notes: } \\
\text { *indicates statistical significance at the 1\% level } \\
\text { **indicates statistical significance at the 5\% level }\end{array}$ \\
\hline
\end{tabular}

\section{B. Foreign Activity (FA)}

On the other hand, a significant negative coefficient for the FA variable indicates that companies which engage in foreign operation with more extensive foreign activity have lower ETR than companies with less extensive foreign activity. This finding supports the contention that companies with more extensive foreign operation have more opportunity to engage in tax planning by taking advantages of tax loopholes such exploiting other differences in the tax rules of different countries and by taking opportunities from tax subsidy agreements with host countries. This finding supports [5] work that corporations with more extensive foreign operations engage in tax planning and report lower ETR.

\section{CONCLUSION AND FUTURE RECOMMENDATION}

Tax collection generates large amounts of revenue and is a vital source of income for government to promote overall economic stability and growth.

It is found that companies engaging in foreign activities have higher ETRs compared to companies with purely domestic activity. The distinct feature of the Malaysian 
capital market is that it has among the lowest corporate income tax rates among ASEAN countries in particular and generally worldwide. Given that the tax rate in Malaysia is relatively low, companies engage in foreign activity are documented to have higher ETR than domestic only companies. On the other hand, interdependence of operational, financial and technology may encourage companies to engage in operations in high-tax countries. Thus, companies engaging in foreign operations are subject to higher foreign tax rates compared with the Malaysian corporate tax rates. Even though foreign activities provide more opportunities for companies to avoid tax, however, in the case of Malaysian companies, they are exposed to higher foreign tax rates. Furthermore, the result by comparing the effective tax rates of companies engaging in foreign activity and domestic only companies, this study responds to [11] assertion which was confirmed by [5] that empirical research does not provide conclusive evidence that companies engaging in foreign activity pay less income tax than domestic-only companies.

With regard to companies with more extensive foreign activities have lower ETR than companies with less extensive foreign activities. This finding is in line with the results documented in several studies, for example [5], [9] and [12]. This is due to the tax benefits available for foreign activities. That is, companies with more extensive foreign activities are able to capture more effective tax planning than companies with less extensive foreign activities. Even though Malaysia has among the lowest corporate income tax rate worldwide, several other tax benefits exist that could be of advantage to companies which extensively engaged in foreign activities. Companies which frequently engage in foreign activities could use their foreign operations to plan income taxation. According to [5], companies engaging in foreign activities have opportunities to avoid income taxation by exploiting differences between the tax rules of different countries and the tax subsidy agreements with host countries. Despite the ability to take advantage of the tax rules of different countries or tax benefit agreements with host countries, Malaysian tax law also provides several tax incentives for companies engaging in foreign operations that could lower taxable income. Thus, the results suggest that companies reporting higher levels of foreign activities are likely to engage in international tax planning, which reduces the corporate effective tax rate.
It remains to conclude this study by suggesting recommendation for future research. This study does not examine the association between corporate tax planning and non-listed companies in Malaysia. In the future, as more data becomes available, one could include tax planning in non-listed companies.

\section{REFERENCES}

[1] Bank Negara Malaysia. (2003). BNM Annual Report 2003. Retrieved 30 October 2005. From Bank Negara Malaysia. [Online]. Available: http://www.portsworld.com/banknegara/annual report 03.htm

[2] J. Slemrod, "The economics of corporate tax selfishness," National Tax Journal, vol. 57, no. 4, pp. 877-899, 2004.

[3] C. S. Armstrong, J. F. Blouin, and D. F. Larcker, "The incentives for tax planning," Journal of Accounting and Economics, vol. 53, pp. $391-411,2012$.

[4] J. Phillips, "Corporate tax planning effectiveness: The role of compensation-based incentives," The Accounting Review, vol. 78, no. 3, pp. 847-874, 2003.

[5] S. O. Rego, "Tax avoidance activities of US multinational corporations," Contemporary Accounting Research, vol. 20, no. 4, pp. 1-35, 2003.

[6] C. Derashid and H. Zhang, "Effective tax rates and the "industrial policy" hypothesis: Evidence from Malaysia," Journal of International Accounting, Auditing and Taxation, vol. 12, no. 1, pp. 45-62, 2003.

[7] D. S. Callihan, "Corporate effective tax rates: A synthesis of the literature," Journal of Accounting Literature, vol. 12, pp. 1-43, 1994.

[8] S. D. Dyreng, M. Hanlon, and E. L. Maydew, "Long-run corporate tax avoidance," The Accounting Review, vol. 83, no. 1, pp. $61-82$, 2008.

[9] S. Leblang, "International double nontaxation," Tax Notes International, vol. 20/7/98, pp. $181-183,1998$.

[10] J. Hines, "Lessons from behavioral responses to international taxation," National Tax Journal, vol. 52, no. 2, pp. 305-322, 1999.

[11] J. Collins and D. Shackelford, "Writers challenge claim of favorable cross-border taxations," Tax Notes, vol. 82, no. 4, pp. 131-134, 1999.

[12] M. N. Harris and S. Feeny, "Habit persistence in effective tax rates," Applied Economics, vol. 35, pp. 951-958, 2003.

[13] T. Shevlin and S. Porter, "The corporate tax comeback in 1987: some further evidence," Journal of American Taxation Association, vol. 14, no. 1, pp. 58-79, 1992.

[14] W. Buijink, B. Janssen, and Y. Schols, Effective Tax Rates for Listed Companies in the OECD, MARC, Maastricht University, 2000 .

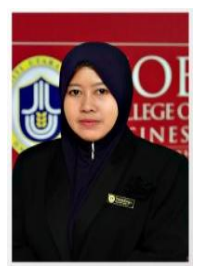

Zaimah Zainol Ariffin is a senior lecturer of the School of Accountancy, College of Business, Universiti Utara Malaysia (UUM COB). She was awarded a Ph.D. in Accounting and Finance from University of Wales, Bangor, United Kingdom in 2007. Her area of interest is Corporate Taxation, Individual Taxation, Tax Avoidance, Managerial Ownership and Small and Medium Enterprise (SME). She has been in service for more than 18 years in Universiti Utara Malaysia. 